Sains Malaysiana 47(1)(2018): 27-34

http://dx.doi.org/10.17576/jsm-2018-4701-04

\title{
Biotechnology: A Powerful Tool for the Removal of Cadmium from Aquatic Systems
}

(Bioteknologi: Alat yang Ampuh untuk Penyingkiran Kadmium daripada Sistem Akuatik)

\section{Rabeea Munawar, EhSan Ullah Mughal*, Amina SadiQ, Hamid MukHTAR, Muhammad NaVEed ZaFar,

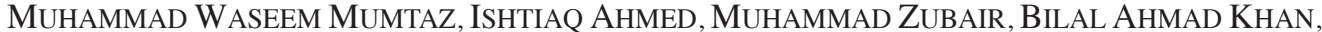 JAMSHAID ASHRAF, ZOFISHAN YOUSAF \& NOREED AKBAR}

\begin{abstract}
The prime objective of the present research work was to evaluate the efficiency of bio-machine for the removal of Cadmium (Cd) from aquatic systems. Aspergillus niger fungus was used as bio-machine to remove Cd from aquatic systems. Twenty three different strains (IIB-1 to IIB-23) were isolated from industrial effluents and the Langmuir and Freundlich models were applied to the best Cadmium removal strain IIB-23 in order to obtain the adsorption parameters. Different parameters such as $\mathrm{pH}$, temperatur e, contact time, initial metal concentratio, and biomass dosage on the biosorption of $C d$ were studied. The percent removal of $C d$ initially increased with an increase in $\mathrm{pH}$ ranging from 5.5-6.5 and then decreased by increasing $\mathrm{pH}$ from 7.0-7.5. An optimized $\mathrm{pH}$ used for Cd removal from aquatic systems was found to be 6.5. Additionally, an optimum amount of biomass was $1.33 \mathrm{~g}$ for the maximum removal of $C d$ from the aqueous solutions with initial metal concentration of $75 \mathrm{mg} / \mathrm{L}$. The results obtained thus indicated that Langmuir model is the best suited for the removal of $C d$ from aquatic systems.
\end{abstract}

Keywords: Adsorption; Aspergillus niger; Bio-machine; Biosorption; Biotechnology; Cadmium

ABSTRAK

Objektif utama penyelidikan ini adalah untuk menilai keberkesanan mesin biologi dalam menyingkirkan kadmium (Cd) daripada sistem akuatik. Kulat Aspergillus niger digunakan sebagai mesin biologi untuk penyingkiran Cd daripada sistem akuatik. Dua puluh tiga strain berbeza (IIB-1 IIB-23) telah dipencilkan daripada efluen industri dan model Langmuir dan Freundlich digunakan untuk penyingkiran kadmium terbaik strain IIB-23 untuk mendapatkan parameter penjerapan. Parameter berbeza seperti $\mathrm{pH}$, suhu, masa hubungan, kepekatan logam pemula dan dos biojisim pada bioserapan CD telah dikaji. Peratus penyingkiran Cd pada mulanya meningkat dengan peningkatan dalam pH antara 5.5-6.5 dan kemudian menurun dengan peningkatan pH daripada 7.0-7.5. PH optimum yang digunakan untuk penyingkiran Cd daripada sistem akuatik adalah 6.5. Di samping itu, sejumlah biojisim optimum adalah $1.33 \mathrm{~g}$ untuk penyingkiran maksimum Cd daripada larutan berair dengan kepekatan logam pemula $75 \mathrm{mg} / \mathrm{L}$. Keputusan yang diperoleh menunjukkan bahawa model Langmuir adalah yang terbaik untuk penyingkiran Cd daripada sistem akuatik.

Kata kunci: Aspergillus niger; bioserapan; bioteknologi; kadmium; mesin biologi; penjerapan

\section{INTRODUCTION}

Heavy metal pollution load in an aquatic system is of great environmental concern as these metals are toxic and non-biodegradable. Due to the increasing anthropogenic activities and use of improper drainage systems of industries and agriculture, these metals are accountable for dangerous chemical pollution of aquatic systems (Chopra $\&$ Pathak 2010). The toxic heavy metals responsible for water pollution are Cadmium (Cd), Zinc (Zn) Chromium $(\mathrm{Cr})$, Nickel $(\mathrm{Ni})$, Lead $(\mathrm{Pb})$ and Mercury $(\mathrm{Hg})$. At higher concentrations (above $\mathrm{LD}_{50}$ values), these metals become toxic but some of these metals such as $\mathrm{Cr}, \mathrm{Ni}$ and $\mathrm{Zn}$ are essential at trace levels for human beings (Newman et al. 2010).
Cadmium is the most toxic metal which causes harmful effects to the humans as well as to environment. It is harmful pollutant originating from mining, ceramics and metal plating, and also causes cancer, kidney and bone diseases in humans. Long-lasting exposure causes liver damage, renal dysfunction and bone degradation $(\mathrm{Ng}$ et al. 2008). Conventional methods used for the removal of heavy metals from waste water include adsorption and evaporation (Ahluwalia \& Goyal 2007; Aksu et al. 1999), ion exchange (Finley et al. 2013), chemical precipitation (Göksungur et al. 2005), chemical reduction (Moses et al. 2003) and different membrane processes (Colditz et al. 1995; Nourbakhsh et al. 1994). The disadvantages regarding conventional techniques are monitoring systems, 
incomplete metal removal (Xiangliang et al. 2005), requirement for expensive equipment and generation of toxic sludge (Kobya et al. 2005).

Biomass is very useful for the accumulation of heavy metals. According to the environmental remediation, biomass must be a waste material and it comes from nature (Sawalha et al. 2006). Different types of biomasses have been obtained from fungi, bacteria, yeast, microbial, plants derived, molds and crab shells (Nagajyoti et al. 2010) which were used for the biosorption of different metals (Martín-González et al. 2006).

Biosorption is the binding and concentration of heavy metals from aqueous solutions (very dilute) by the use of dead, microbial and plant derived biomass. Biomass acts as an ion exchanger and chemical substance of biological origin. It was actually the cell wall of certain biomass which is responsible for the biosorption. Biosorption efficiency depends upon specificity and affinity of the biosorbent and their physical and chemical conditions in effluents. Biosorption is highly competitive because of cost effectiveness, regeneration of metals, no sludge formation, no additional nutrient required and heavy metal selectivity (Pittman et al. 2011). Due to the structural complexity of the microorganism there are many ways for the metal uptake by the microbial organism. According to the various criteria, the biosorption mechanisms are classified via metabolism dependence, biosorption mechanism as metabolism and non-metabolism dependent. Similarly, on the metal removal from the solution, biosorption may be classified as extra-cellular accumulation, cell surface sorption and intra-cellular accumulation. Depending upon metabolic biosorption, transport of the metal across the cell membrane yields intra-cellular accumulation which is highly dependent upon the cell's metabolism. It means that biosorption only takes place with viable cells. It is associated with the active defense system of the microorganism, which further reacts in the presence of toxic metal. According to non-metabolic dependent biosorption, metal uptake is the physiochemical interaction between the functional groups present on the microbial cell surface and metal, during non-metabolic dependent biosorption. It is based upon chemical precipitation, ion exchange and physical adsorption. The cell wall of microbial biomass is made up of proteins, polysaccharides and lipids. Metal binding takes place with functional groups such as sulphate, phosphate, carboxyl, hydroxyl and amino groups. This type of biosorption is reversible and fast (Borcherding 2014).

Many researchers have been focused upon the characteristics of metal uptake by using fungi, particularly when the heavy metals present at low and different concentrations rather than the current interest upon microbial detoxification of industrial effluents.

As for as the removal of toxic metals from polluted aquatic systems are concerned, there are numerous studies carried out with mechanistic approach of physico-chemical adsorption. In this context, we embarked a project aiming at the isolation of Aspergillus niger as fungal biomass from the industrial effluents of Pakistan. The isolated fungal biomass was investigated as efficient biosorbent for the removal of $\mathrm{Cd}$ from industrial waste water by employing batch biosorption studies.

\section{MATERIALS AND METHODS}

\section{SAMPLE COLLECTION AND PRESERVATION}

Samples of different industrial effluents such as textile, pharmaceuticals, and leather were collected from Quid-eAzam industrial estates Kot Lakh path, Lahore, Pakistan (Figure 1). Samples were collected (1.5 L of each) in sterilized plastic containers. After collection samples were preserved first into ice box and then shifted to research laboratory (Institute of Industrial and Biotechnology Department GCU Lahore) and kept in refrigerator at $4^{\circ} \mathrm{C}$ to stop any physico-chemical change and microbial activity.

\section{DETERMINATION OF HEAVY METAL CONCENTRATION}

Initial as well as post biosorption treatment metal $(\mathrm{Cd})$ concentration in the industrial effluent was determined using Atomic Absorption Spectrophotometer ModelAA7000F, Shimadzu Japan and standard of Merck pharmacy was used having concentration range of 1000 ppm.

\section{ISOLATION OF BIOSORBENTS}

Potato dextrose agar (PDA) medium was prepared, (100 $\mathrm{mg} / \mathrm{L}$ ) of Cd solution was added, Levofloxacin $500 \mathrm{mg}$ was also added into the medium to inhibit the bacterial growth and make the volume up to the mark. Nutrient agar medium was prepared for bacterial growth followed by pouring of medium into the plates under the laminar flow. After solidifying media, industrial effluents were spread onto the plates by using micropipette. Plates were incubated at $30^{\circ} \mathrm{C}$ for 6-7 days. When colonies were seen, re-inoculation of hyphen tips was done to purify the isolates. To get pure cultures of fungal species, they were re-inoculated on the new plates for three times. From the established culture of 6-7 days, spores were inoculated onto the PDA slants at $30^{\circ} \mathrm{C}$, pure culture were obtained and used for inocula preparation. These slants were stored at $4^{\circ} \mathrm{C}$ for further use.

\section{EVALUATION OF MICROBIAL STRAINS BY SCREENING}

Nutrient broth was prepared in a conical flask and cotton plugged. The prepared medium was sterilized in autoclave for $20 \mathrm{~min}$ at $151 \mathrm{bs}$. and $121^{\circ} \mathrm{C}$. After sterilization, the medium was cooled to room temperature. Under laminar flow cabinet, the inoculum was added in it. For three days, those cultures were incubated on rotary shaker at $30^{\circ} \mathrm{C}$ and $160 \mathrm{rpm}$. After $72 \mathrm{~h}$, fungal growth was observed and biomass was centrifuged at $6000 \mathrm{rpm}$ for $10 \mathrm{~min}$. Pallet was taken and makes $\mathrm{Cd}$ solution of known concentration of $100 \mathrm{ppm}$ and added into it. Treat for $1 \mathrm{~h}$ at rotary shaker and again centrifuged at $6000 \mathrm{rpm}$ for $10 \mathrm{~min}$. Supernatant was collected and pallets were separated for determination 


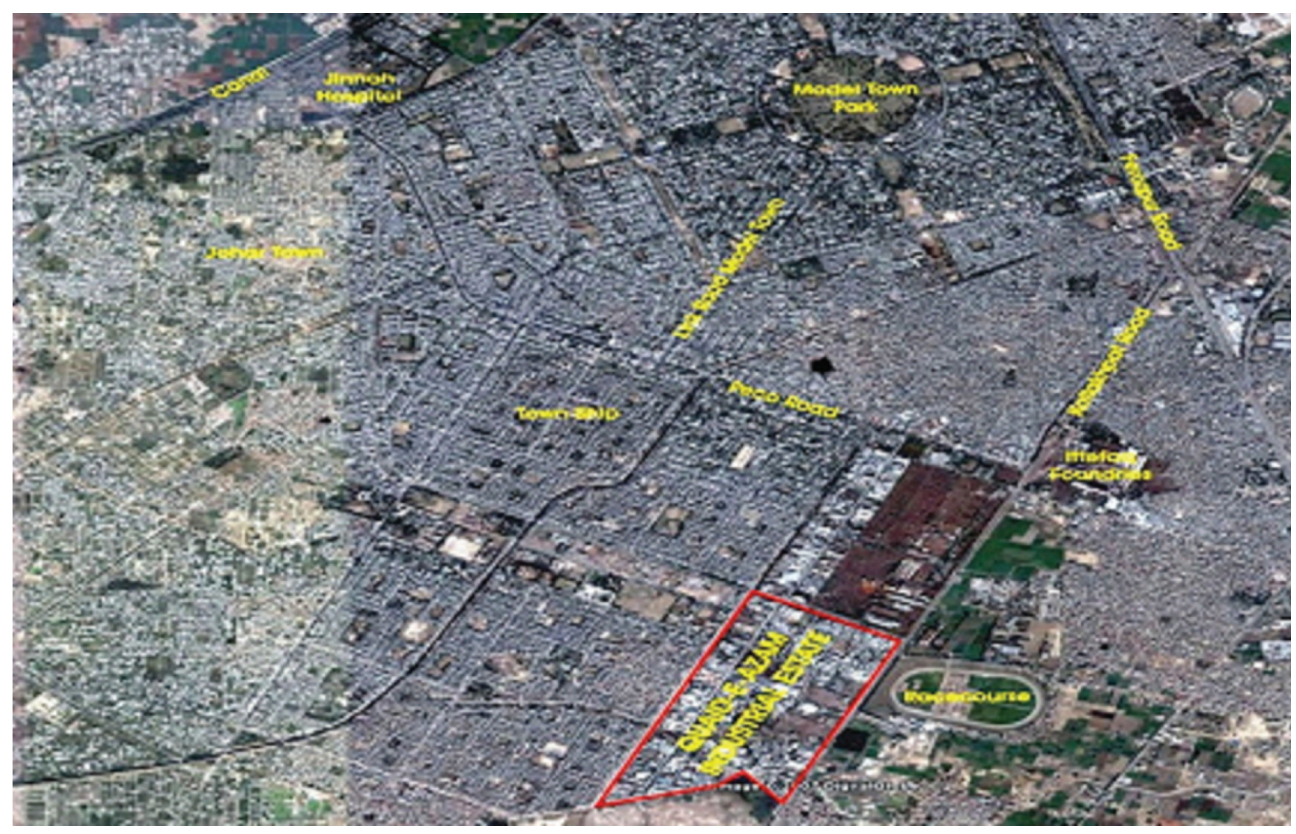

FIGURE 1. Map and view of Quid-e-Azam Industrial Estates Kot Lakh Path, Lahore, Pakistan

of strain shows best Cd removal. Supernatant was run onto the atomic absorption spectroscopy. The strain having least amount of $\mathrm{Cd}$ shows best cadmium removal. The best results showed by a fungal strain which was used for further biosorption studies.

\section{INOCULUM PREPARATION}

The inoculum was prepared by taking $0.2 \mathrm{~g}$ nutrient broth in a $250 \mathrm{~mL}$ conical flask and $20 \mathrm{~mL}$ distilled water was added to it. After dissolving and diluting volume up to 25 $\mathrm{mL}$ with distilled water. The flask was Cotton plugged and autoclaved at $121^{\circ} \mathrm{C}$ at $15 \mathrm{lbs}$ pressure for $15 \mathrm{~min}$. Czepekdox medium was used for fungal growth, consisting of $(\mathrm{g} / \mathrm{L}): \mathrm{KH}_{2} \mathrm{PO}_{4} 7.0 ;\left(\mathrm{NH}_{4}\right)_{2} \mathrm{SO}_{4}: 1.0 ; \mathrm{K}_{2} \mathrm{HPO}_{4}$ : 2.0; glucose 10 , yeast extracts, 0.6 mixed in distilled water and volume raised to 1.0 liter. From which $25 \mathrm{~mL}$ was transferred to separate conical flask of $250 \mathrm{~mL}$. A slant having A. niger was taken and $10 \mathrm{~mL}$ of the sterilized distilled water added. By using inoculating needle, the slant was then scratched and spore suspension was made. For the inoculation of cultural media, one milliliter of this spore suspension was used. Samples were filtered by using syringe filter paper nylon membrane having porosity 0.22 $\mu \mathrm{m}$ (AISIMO).

\section{SUBMERGED FERMENTATION}

The fungal strains were inoculated in liquid media in $250 \mathrm{~mL}$ Erlenmeyer flasks and then these flasks were cotton plugged and kept in autoclave for $15 \mathrm{~min}$ at 15 lbs. and $121^{\circ} \mathrm{C}$. After sterilization, the media was cooled down at room temperature and inoculum was added in it in laminar air flow. Those cultures were incubated on rotary shaker at $160 \mathrm{rpm}$ and $30^{\circ} \mathrm{C}$ for $72 \mathrm{~h}$. After 3 days, fungal biomass was centrifuged. All the experiments were performed in triplicate. Culture broth was centrifuged at $6000 \mathrm{rpm}$ for $10 \mathrm{~min}$ after three days of incubation period. Supernatant was collected and pallets were separated for the determination of dry cell mass. The supernatant was used for further biosorption studies.

\section{IDENTIFICATION OF FUNGAL SPECIE}

The fungal specie Aspergillus niger was identified with the help of expert of Department of Botany, University of the Punjab, Lahore, Pakistan and Government College University (GCU) Lahore, Pakistan, and thus was used as biosorbent for the removal of heavy metals like $\mathrm{Cd}$ from the waste water.

\section{MORPHOLOGICAL CHARACTERISTICS AND TAXONOMIC POSITION OF ASPERGILLUS NIGER}

Colonies of Aspergillus niger were grew fast upon plates and gives appearance like cotton. A little bit contamination was appeared; hence, pure colonies of black color were picked up with the help of inoculating loop and transferred to slants. These were initially black in colorbut with the passage of time; the colonies became blackish to brownish black. Conidiophores were narrowly placed with hyaline erect stem. Vesicles were globular to club shaped over the surface of which rod-shaped sterigmata are born. Conidiophores were 949-1060 $\mu \mathrm{m}$ in length, hyaline and finely roughened, smooth-walled and had conical terminal vesicles ( $42 \mu \mathrm{m}$ in diameter), which supported a single row of phialides with 14-16 $\mu \mathrm{m}$ in length (Figure 2).

\section{METAL UPTAKE AND BIOSORPTION EFFICIENCY}

The uptake of metal ions was calculated by the given formula: 

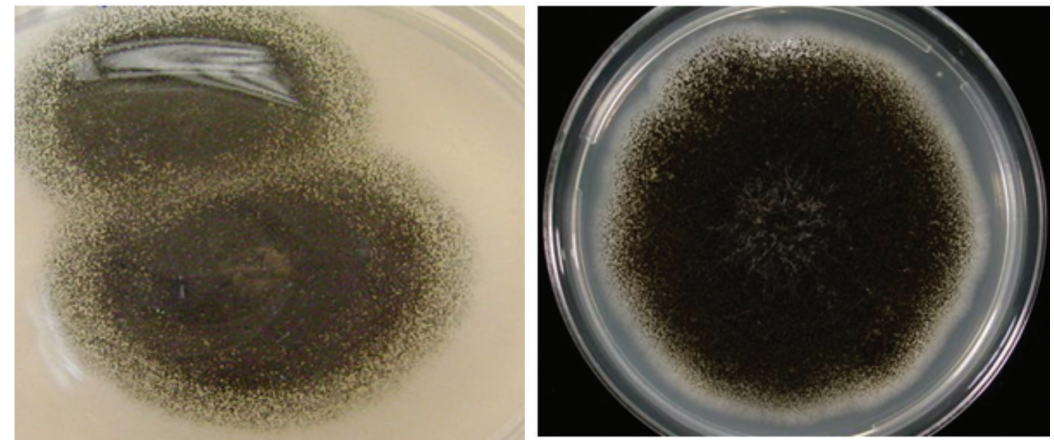

FIGURE 2. Images showing colonies of microbes with best Cd removal

$\mathrm{q}=\mathrm{V}(\mathrm{Ci}-\mathrm{Cf}) / \mathrm{m}$

where $\mathrm{Q}$ is the $\mathrm{mg}$ of metal ions per $\mathrm{g}$ of biosorbent; $\mathrm{V}$ is the volume of reaction; $\mathrm{Ci}$ is the initial metal concentration; $\mathrm{Cf}$ is the final metal concentration; and $\mathrm{M}$ is the amount of biosorbent.

The metal ion concentration in the filtrate was determined by using the Flame Atomic Absorption Spectrometry, AA-7000F Shimadzu Japan.

The efficiency of heavy metal ions was calculated by the following formula:

$$
\mathrm{Y}=\mathrm{Ci}-\mathrm{Cf} / \mathrm{Ci} \times 100
$$

where $\mathrm{Y}$ is the percentage $\mathrm{Cd}$ removal; $\mathrm{Ci}$ is the initial $\mathrm{Cd}$ concentration; and $\mathrm{Cf}$ is the final $\mathrm{Cd}$ concentration.

\section{REPRODUCIBILITY}

All the experiments were performed in triplicates. Controls were also run without addition of biosorbent using the same protocol. All the parameters were identified after the screening of best Cd removal strain that is Aspergillus niger was used for the optimization of biomass amount by using different batch biosorption experiments as well as for kinetic isotherms.

\section{RESULTS AND DISCUSSION}

\section{ISOLATION AND SCREENING OF BEST CADMIUM REMOVAL STRAIN}

The results indicated that best Cd removal strain is IIB-23 specie because percentage removal of $\mathrm{Cd}$ is higher in that specie (Figure 3). Furthermore, this species is identified and used for the analysis of biosorption parameters. Graph depicted that IIB-23 specie have least amount of $\mathrm{Cd}$ left i.e. $0.332(\mathrm{mg} / \mathrm{L})$ so it is a best $\mathrm{Cd}$ removal strain used for further biosorption studies. Cadmium ions from industrial waste water were absorbed more rapidly within 15-20 min than other ions such as Iron $(\mathrm{Fe})$, Copper $(\mathrm{Cu})$, and Lead $(\mathrm{Pb})$ by $A$. niger biomass. Experiments indicated that equilibrium reached within 20 min while using industrial waste water samples in comparison to the single ions solution equilibrium reached within $30 \mathrm{~min}$. The removal percentage order at equilibrium was: $\mathrm{Cd}(95 \%), \mathrm{Pb}(88 \%)$, $\mathrm{Fe}(70 \%), \mathrm{Cu}(60 \%), \mathrm{Ni}(48.9 \%)$ and $\mathrm{Zn}(15.4 \%)$ (Goyal et al. 2003).

The results indicated that best $\mathrm{Cd}$ removal strain is fungal specie, Aspergillus niger, used for further biosorption parameters. It is an efficient fungus used for the biosorption of heavy metals. It is selected on the basis of its resistance to multi-metals and major occurrence.

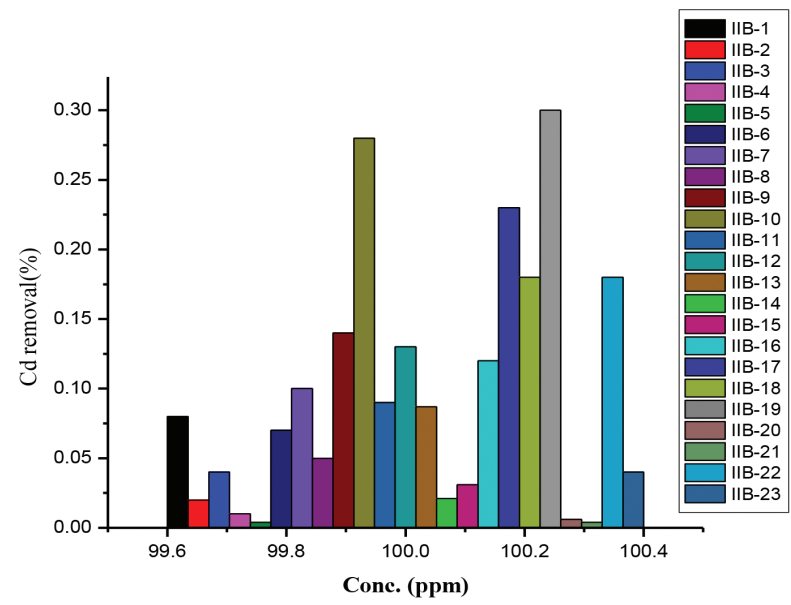

FIGURE 3. Results of isolated microbial strains showing Cd removal

\section{OPTIMIZATION OF PARAMETERS}

Effect of $\mathrm{pH}$ The results indicated that optimized $\mathrm{pH}$ for the biosorption of $\mathrm{Cd}$ by using Aspergillus niger as adsorbent is 6.5 (Figure 4). It starts increasing from $\mathrm{pH}$ 5.5-6.5 which is an acidic media further it starts decreasing from $\mathrm{pH}$ 7-7.5 and conditions for this parameter are $\mathrm{pH}$ 5.5-7.5 (Wilhelmi \& Duncan 1995), temperature $30^{\circ} \mathrm{C}$, adsorbent amount $1 \mathrm{~mL}$ in the form of spore suspension and initial Cd concentration is $100(\mathrm{mg} / \mathrm{L})$ (Joo et al. 2010). The biosorption process for heavy metals optimized at $\mathrm{pH}$ (5.0-5.2) showed the ionic strength affects the adsorption between the solute and fungal biomass. Biomass connection with water molecules bounded to each other with an electrical double layer and showed the 
electrostatic interaction (Volesky \& May-Phillips 1995). So, the adsorption process decreased by the increasing the electrostatic interaction. The metal uptake dependence upon $\mathrm{pH}$ is specifically related to the chemistry of metal in solution and functional groups present on the biomass (Park et al. 1999). The approach of the metal cation is restricted because the surface ligands are closely associated with the hydronium ion at lower $\mathrm{pH}$ of 2-3 and due to the presence of repulsive forces, sorption of the metals at lower $\mathrm{pH}$ become decreased and dissociation of carboxyl group is not occur and cannot bind to the fungal cell wall. The cell surface sites are closely associated to the $\mathrm{H}^{+}$ions and making them unavailable for metal cation at lower $\mathrm{pH}$ (Yin et al. 1999).

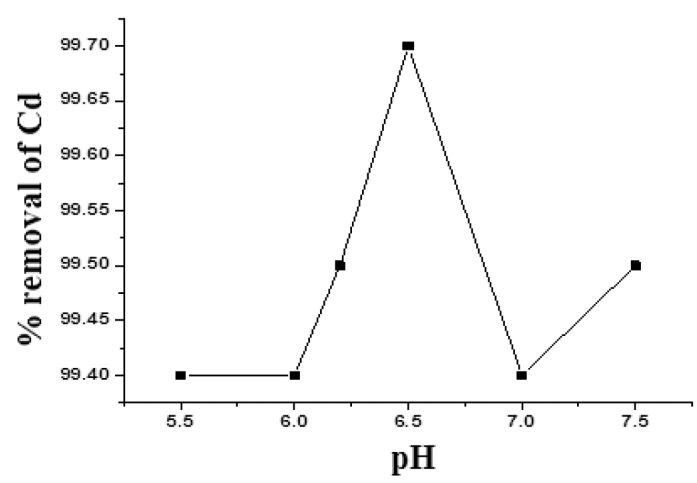

FIGURE 4. Percent (\%) removal of $\mathrm{Cd}$ at different values of $\mathrm{pH}$

Metal Uptake at Different Metal Concentrations Figure 5 illustrates that due to the increase of metal uptake initially increase removal of metal and then goes on decreasing. The maximum metal uptake was obtained at $75 \mathrm{ppm}$ initial metal concentration. The percent (\%) Cd removal efficiency was observed in direct relation to the biomass size until equilibrium was attained and biomass dosage was optimized by using batch biosorption studies in which the optimized amount of biomass was $1.33 \mathrm{~g}$ having concentration of solution $75 \mathrm{mg} / \mathrm{L}$.

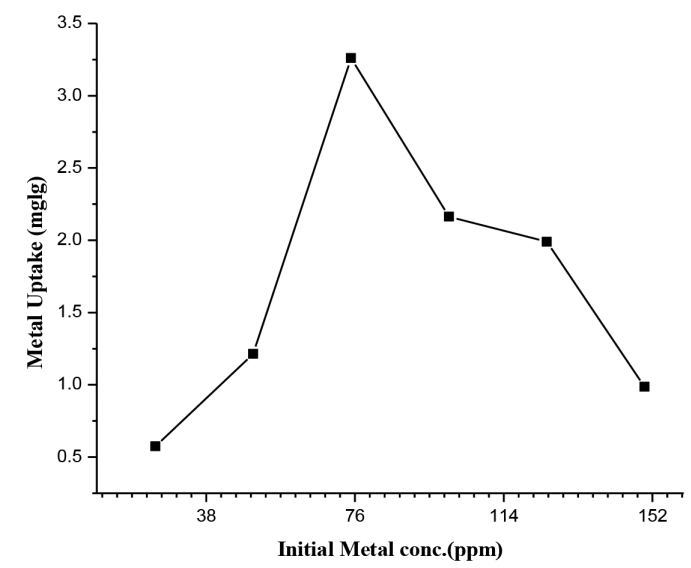

FIGURE 5. Metal uptake at different metal concentrations
Percent (\%) Removal of Cd at Different Biomass Amount Figure 6 shows that initial biomass size increases the removal of $\mathrm{Cd}$ and then it gradually goes on equilibrium. The optimized biomass value is 1.33 in which concentration of solution is $75(\mathrm{mg} / \mathrm{L})$, volume of the solution is 100 $\mathrm{mL}$, adsorbent size varying from $0.19-0.33, \mathrm{pH} 6.5$ and temperature is $30^{\circ} \mathrm{C}$. It has been observed that by using Aspergillus niger as adsorbent, percentage removal of $\mathrm{Cd}$ metal increased due to the increasing concentration of biomass. The maximum removal of $\mathrm{Cd}$ was achieved at biomass dose of $1.33 \mathrm{~g}$ with percentage removal of $97 \%$ was achieved. Therefore, it can be concluded that optimum amount of biomass was $1.33 \mathrm{~g}$ for the maximum removal of $\mathrm{Cd}$ from the aqueous solutions with initial metal concentration of $75 \mathrm{mg} / \mathrm{L}$. Adsorption experiments were carried out by varying amount of biomass dosage 0.19 $0.33 \mathrm{~g}$ in mixed ions solution. The maximum biosorption efficiency was achieved at biomass dose of $1.33 \mathrm{~g} / \mathrm{L}$ with slight significant increase in percentage removal at lower biosorbent amount.

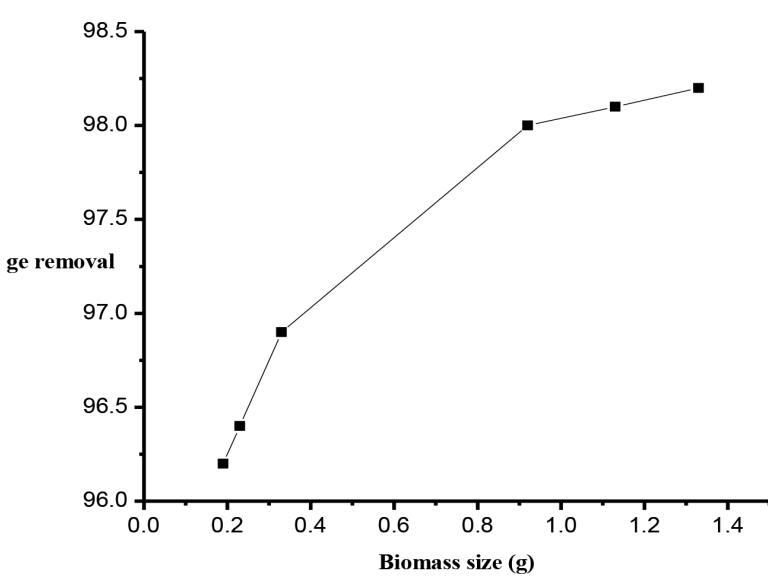

FIGURE 6. Percent (\%) removal of $\mathrm{Cd}$ at different biomass amount

Biosorption Isotherms These are graphical curves which show relationship between equilibrium concentration at uniform temperature and sorbatesorbed by the adsorbent. The biosorption isotherms for $\mathrm{Cd}$ onto the fungal strain were studied in batch experiments by varying concentrations. Therefore, Langmuir and Freundlich isotherms were successfully applied for the verification of analysis.

Langmuir Biosorption Isotherm It tells about monolayer adsorption which means that no adsorbate deposits on it. The number of active sites is static and homogenous distribution on the sorbent surface occurs (Robbins 2012).

The Langmuir isotherm equation is linear and which is represented as (Doyle 1963).

$$
\mathrm{Ce} / \mathrm{qe}=\mathrm{Ce} / \mathrm{qm}+1 / \mathrm{R}_{\mathrm{L}} \mathrm{qm}
$$


where RL is the Langmuir constant; Qe is the adsorption capacity; $\mathrm{Ce}$ is the equilibrium concentration; and Qm is the maximum adsorption capacity.

The Langmuir isotherm can be clearly identified by the following equation (Bardy et al. 2005; Villaescusa et al. 2011),

$$
\mathrm{RL}=1 / 1+\mathrm{KaC}_{0}
$$

Freundlich Biosorption Isotherm The Freundlich isotherm based upon multilayer adsorption and it tells about heterogeneous surface. It is plotted between concentration of solute in a liquid and concentration of solute on the surface of adsorbent.

The Linear equation for Freundlich isotherm is given as (Zhou \& Kiff 1991),

$$
\operatorname{lnqe}=\operatorname{lnk}_{\mathrm{f}}+1 / \mathrm{n} \operatorname{lnCe}
$$

where $\mathrm{Ce}$ is the equilibrium concentration $(\mathrm{mg} / \mathrm{L}) ; \mathrm{K}_{\mathrm{f}}$ is the distribution coefficient; $\mathrm{N}$ is the intensity of adsorbtion; and Qe is the adsorption capacity ( $\mathrm{mg} / \mathrm{g}$ ).

Comparison of Langmuir and Freundlich Isotherms Figure 7 concludes that slope for Langmuir model is 0.0936 , intercept is -0.0084 and $\mathrm{R}^{2}$ value is $99 \%$. According to Freundlich isotherm (Figure 8), the value of slope is 0.1085 , intercept is 1.260 and $\mathrm{R}^{2}$ is $21 \%$. Larger the value of $\mathrm{R}^{2}$, the better is the isotherm model. So the Langmuir model is best fitted to the biosorption of $\mathrm{Cd}$ from Aspergillus niger biomass.

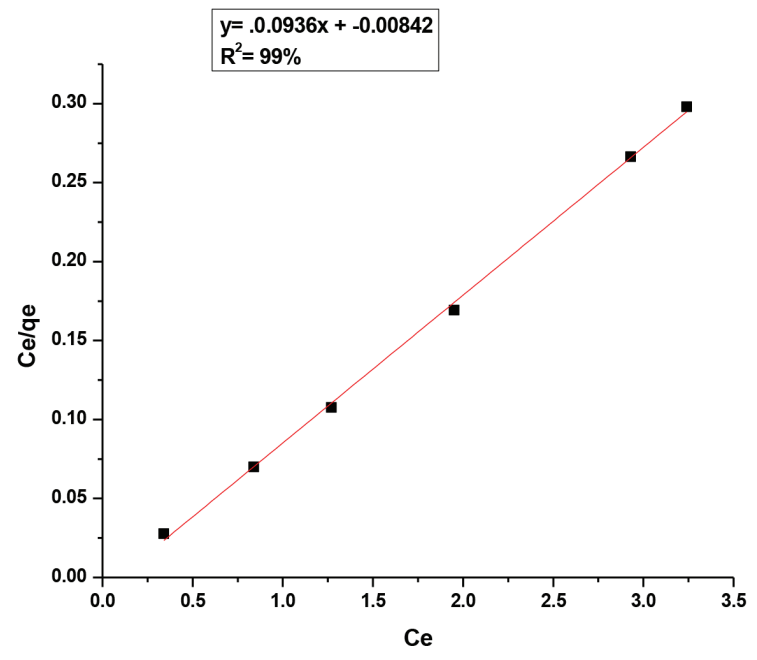

FIGURE 7. Langmuir isotherm for Cd biosorption on Aspergillus niger

\section{CONCLUSION}

In the present study, a fungal strain Aspergillus niger was used as adsorbent for the removal of $\mathrm{Cd}$ from end of pipe waste water (effluents). For this purpose batch biosorption experiments were done. The study for the optimum $\mathrm{pH}$

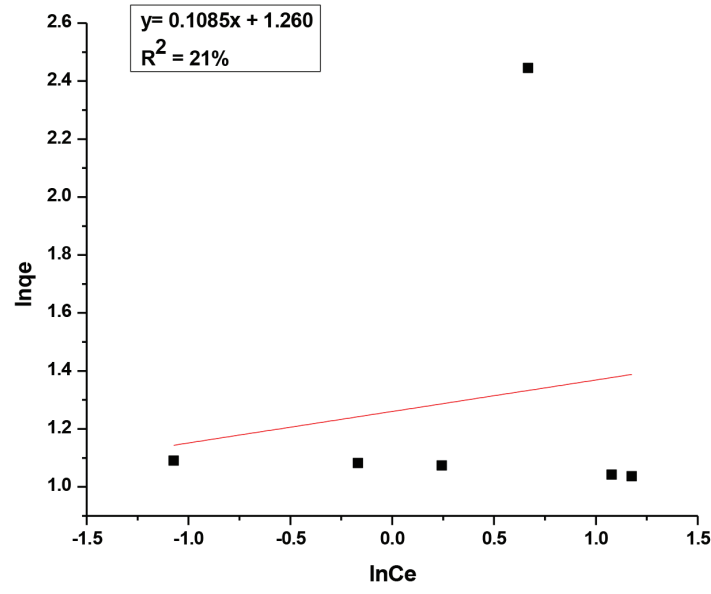

FIGURE 8. Freundlich isotherm for Cd biosorption on Aspergillus niger

showed that fungal adsorbent worked maximum at $\mathrm{pH} 6.5$ and optimized amount of biomass was $1.33 \mathrm{~g}$ which was achieved at $75 \mathrm{ppm}$ Cd concentration initially and $98.97 \%$ of Cd was removed from the solution. Applicability of Langmuir and Freundlich methods were assessed using experimental data. The experimental results showed Langmuir model was best fitted to our experimental data. Furthermore, it could efficiently be used as potential and cost-effective substituent regarding to imported and costly sorbents currently being applied. Biosorption, by using microbial biomass i.e. algae, fungi, bacteria has been considered as best alternative biological technique to the existing technologies used for the removal of heavy metals from the aqueous solutions. Fungal adsorbents are the economic because these microbes were grown upon PDA and Czepekdox media which were easily available and commercially economical. By using un-sophisticated fermentation techniques, a huge amount of fungi can grow on an inexpensive growth media. So it is recommended that fungal biomass can be used for the removal of metal ions from waste water because biomass can regenerate as well.

\section{REFERENCES}

Ahluwalia, S.S. \& Goyal, D. 2007. Microbial and plant derived biomass for removal of heavy metals from wastewater. Bioresource Technology 98: 2243-2257.

Aksu, Z., Egretli, G. \& Kutsal, T. 1999. A comparative study for the biosorption characteristics of chromium (VI) on caalginate, agarose and immobilized c vulgaris in a continuous packed bed column. Journal of Environmental Science \& Health Part A 34: 295-316.

Borcherding, N. 2014. Noncanonical Wnt signaling in breast cancer initiation and progression. Thesis. University of Iowa (Unpublished).

Bardy, G.H., Lee, K.L., Mark, D.B., Poole, J.E., Packer, D.L., Boineau, R., Domanski, M., Troutman, C., Anderson, J. \& Johnson, G. 2005. Amiodarone or an implantable cardioverter-defibrillator for congestive heart failure. New England Journal of Medicine 352: 225-237. 
Chopra, A. \& Pathak, C. 2010. Biosorption technology for removal of metallic pollutants-an overview. Journal of Applied \& Natural Science 2: 318-329.

Colditz, G.A., Hankinson, S.E., Hunter, D.J., Willett, W.C., Manson, J.E., Stampfer, M.J., Hennekens, C., Rosner, B. \& Speizer, F.E. 1995. The use of estrogens and progestins and the risk of breast cancer in postmenopausal women. New England Journal of Medicine 332: 1589-1593.

Doyle, R.G. 1963. The consolidation characteristics of peat as determined from the one-dimensional consolidation test. Thesis. University of British Columbia (Unpublished).

Finley, R.L., Collignon, P., Larsson, D.J., McEwen, S.A., Li, X.Z., Gaze, W.H., Reid-Smith, R., Timinouni, M., Graham, D.W. \& Topp, E. 2013. The scourge of antibiotic resistance: The important role of the environment. Clinical Infectious Diseases 57: 704-710.

Göksungur, Y., Üren, S. \& Güvenç, U. 2005. Biosorption of cadmium and lead ions by ethanol treated waste baker's yeast biomass. Bioresource Technology 96: 103-109.

Goyal, N., Jain, S. \& Banerjee, U. 2003. Comparative studies on the microbial adsorption of heavy metals. Advances in Environmental Research 7: 311-319.

Joo, J.H., Hassan, S.H. \& Oh, S.E. 2010. Comparative study of biosorption of $\mathrm{Zn} 2+$ by Pseudomonas aeruginosa and Bacillus cereus. International Biodeterioration \& Biodegradation 64: 734-741.

Kobya, M., Demirbas, E., Senturk, E. \& Ince, M. 2005. Adsorption of heavy metal ions from aqueous solutions by activated carbon prepared from apricot stone. Bioresource Technology 96: 1518-1521.

Moses, J.W., Leon, M.B., Popma, J.J., Fitzgerald, P.J., Holmes, D.R., O'Shaughnessy, C., Caputo, R.P., Kereiakes, D.J., Williams, D.O. \& Teirstein, P.S. 2003. Sirolimus-eluting stents versus standard stents in patients with stenosis in a native coronary artery. New England Journal of Medicine 349: 1315-1323.

Martín-González, A., Díaz, S., Borniquel, S., Gallego, A. \& Gutiérrez, J.C. 2006. Cytotoxicity and bioaccumulation of heavy metals by ciliated protozoa isolated from urban wastewater treatment plants. Research in Microbiology 157: 108-118.

Nagajyoti, P., Lee, K. \& Sreekanth, T. 2010. Heavy metals, occurrence and toxicity for plants: A review. Environmental Chemistry Letters 8: 199-216.

Newman, A.B., Walter, S., Lunetta, K.L., Garcia, M.E., Slagboom, P.E., Christensen, K., Arnold, A.M., Aspelund, T., Aulchenko, Y.S. \& Benjamin, E.J. 2010. A meta-analysis of four genome-wide association studies of survival to age 90 years or older: The cohorts for heart and aging research in genomic epidemiology consortium. The Journals of Gerontology Series A: Biological Sciences and Medical Sciences 65: 478-487.

Ng, A.K.L., Zhang, H., Tan, K., Li, Z., Liu, J.H., Chan, P.K.S., Li, S.M., Chan, W.Y., Au, S.W.N., Joachimiak, A., Walz, T., Wang, J.H. \& Shaw, P.C. 2008. Structure of the influenza virus A H5N1 nucleoprotein: Implications for RNA binding, oligomerization, and vaccine design. The FASEB Journal 22(10): 3638-3647.

Nourbakhsh, M., Sag, Y.,Özer, D., Aksu,Z., Kutsal, T. \& Caglar, A. 1994. A comparative study of various biosorbents for removal of chromium (VI) ions from industrial waste waters. Process Biochemistry 28: 1-5.
Park, J.K., Jin, Y.B. \& Chang, H.N. 1999. Reusable biosorbents in capsules from Zoogloea ramigera cells for cadmium removal. Biotechnology and Bioengineering 63: 116-121.

Pittman, J.K., Dean, A.P. \& Osundeko, O. 2011. The potential of sustainable algal biofuel production using wastewater resources. Bioresource Technology 102: 17-25.

Robbins, C.R. 2012. Chemical composition of different hair types. In Chemical and Physical Behavior of Human Hair. New York: Springer. pp. 105-176.

Sawalha, M.F., Peralta-Videa, J.R., Romero-González, J. \& Gardea-Torresdey, J.L. 2006. Biosorption of Cd (II), Cr (III), and $\mathrm{Cr}$ (VI) by saltbush (Atriplex canescens) biomass: Thermodynamic and isotherm studies. Journal of Colloid and Interface Science 300: 100-104.

Villaescusa, I., Fiol, N., Poch, J., Bianchi, A. \& Bazzicalupi, C. 2011. Mechanism of removal by vegetable wastes: The contribution of $\pi-\pi$ interactions, hydrogen bonding and hydrophobic effect. Desalination 270: 135-142.

Volesky, B. \& May-Phillips, H. 1995. Biosorption of heavy metals by Saccharomyces cerevisiae. Applied Microbiology and Biotechnology 42: 797-806.

Wilhelmi, B. \& Duncan, J. 1995. Metal recovery from Saccharomyces cerevisiae biosorption columns. Biotechnology Letters 17: 1007-1012.

Xiangliang, P., Jianlong, W. \& Daoyong, Z. 2005. Biosorption of $\mathrm{Pb}$ (II) by Pleurotus ostreatus immobilized in calcium alginate gel. Process Biochemistry 40: 2799-2803.

Yin, P., Yu, Q., Jin, B. \& Ling, Z. 1999. Biosorption removal of cadmium from aqueous solution by using pretreated fungal biomass cultured from starch wastewater. Water Research 33: 1960-1963.

Zhou, J.L. \& Kiff, R.J. 1991. The uptake of copper from aqueous solution by immobilized fungal biomass. Journal of Chemical Technology and Biotechnology 52: 317-330.

Rabeea Munawar, Ehsan Ullah Mughal*, Muhammad Waseem Mumtaz, Muhammad Zubair, Jamshaid Ashraf,Zofishan Yousaf \& Noreed Akbar

Department of Chemistry, University of Gujrat

Gujrat, 50700

Pakistan

Amina Sadiq

Department of Chemistry

Govt. College Women University

Sialkot 51300

Pakistan

Hamid Mukhtar

Institute of Industrial Biotechnology

GC University, Lahore 54000

Pakistan

Muhammad Naveed Zafar

Department of Chemistry

Quaid-i-Azam University

Islamabad-45320

Pakistan

Ishtiaq Ahmed

Karlsruhe Institute of Technology (KIT)

Institute for Biological Interfaces (IBG-1) 
Hermann-von-Helmholtz-Platz

D-76344 Eggenstein-Leopoldshafen

Germany

Bilal Ahmad Khan

Department of Chemistry

University of Azad Jammu and Kashmir, Muzaffarabad

Pakistan
*Corresponding author; email: ehsan.ullah@uog.edu.pk

Received: 16 February 2017

Accepted: 15 June 2017 